\title{
Pyroelectric $\mathrm{Bi}_{5-\mathrm{x}}\left(\mathrm{Bi}_{2} \mathrm{~S}_{3}\right)_{39} \mathrm{I}_{12} \mathrm{~S}$ : Fibonacci Superstructure, Synthesis Options and Solar Cell Potential
}

\author{
Hans Hermann Otto \\ Materialwissenschaftliche Kristallographie, Clausthal-Zellerfeld, Germany \\ Email: hhermann.otto@web.de
}

Received 20 February 2015; accepted 18 April 2015; published 27 April 2015

Copyright (C) 2015 by author and Scientific Research Publishing Inc.

This work is licensed under the Creative Commons Attribution International License (CC BY). http://creativecommons.org/licenses/by/4.0/

(c) (i) Open Access

\begin{abstract}
Previously, synthetic hexagonal bismuth sulfide iodide (polar space group $P 6_{3}, a=15.629(3) \AA \AA, c=$ 4.018(1) $\AA, Z=2$ ) has been described by the rather unsatisfactory fractional formula $B_{19 / 3} I S_{9}$ [1][3]. A redetermination of the structure using old but reliable photographic intensity data indicated the presence of additional split positions and reduced atomic occupancies. From the observed pattern of this "averaged" structure a consistent model of a superstructure with lattice parameters of $a^{\prime}=\sqrt{13} \cdot a=56.35(1) \AA ̊ ., c^{\prime}=c$, and a formula $B i_{5-x}\left(B i_{2} S_{3}\right)_{39} I_{12} S$ emerged, with 2 formula units in $a$ cell of likewise $\mathrm{P6}_{3}$ space group. Structural modulation may be provoked by the space the lone electron pair of Bi requires. When $B i$ on the $0,0, z$ position of the "averaged" cell is transferred to two general six-fold sites and one unoccupied twofold one of the super-cell, more structural stability is guaranteed due to compensation of its basal plane dipole momentum. Owing to the limited intensity data available, more details of the superstructure are not accessible yet. Some physical properties and solar cell application are discussed together with suggestions of ambient temperature synthesis routes of c-axis oriented nano-rod sheets.
\end{abstract}

\section{Keywords}

Hexagonal Bismuth Sulfide Iodide, Superstructure, Sub-Cell, Fibonacci Numbers Sequence, Pyroelectricity, Crystal Growth, Nano-Rods, Completely Inorganic Solar Cell, Twin-Cell, Photocatalyst

\section{Introduction}

Half a century ago the synthesis of acentric hexagonal $\mathrm{Bi}_{19 / 3} \mathrm{IS}_{9}$ by chemical transport reaction has been reported and a structure proposal based on a sub-cell relationship was given, showing a Fibonacci relation between their 
lattice parameters with $\mathrm{a}_{\text {sub }}=\mathrm{a} / \sqrt{ } 13$ [1] [2]. Later the crystal structure of this compound has been described by others [3], followed by syntheses of the isotypicbismuth sulfide bromide and chloride, respectively [4] [5]. Eventually, Mariolacos [6] determined the crystal structure of the bromide sulfosalt. The formula was given as $\mathrm{Bi}\left(\mathrm{Bi}_{2} \mathrm{~S}_{3}\right)_{9} \mathrm{Br}_{3}$ despite the fact that the assumed unit cell actually contains fewer atoms. However, the structure determinations by Miehe \& Kupcic [3] and Mariolacos [6] appear to be less reliable. Although the author of this contribution had previously pointed out parallels to other compounds with a superstructure of multiplicity 13 , this reasonable approach has not been pursued further [1]. For instance, benstonite, $\mathrm{Ca}_{7} \mathrm{Ba}_{6}\left(\mathrm{CO}_{3}\right)_{13}$ [7], reveals ordering of the differently size dcations on sites of the calcite structure that leads to a superstructure with a geometrical relations similar to the unit cell and sub-cell of the bismuth sulfide iodide. Further examples for such geometrical relations are found in clockmannite, CuSe, senaite, $\mathrm{Pb}(\mathrm{Ti}, \mathrm{Fe}, \mathrm{Mn}, \mathrm{Mg})_{24} \mathrm{O}_{38}$ [8] and davidite, (La, $\mathrm{Ca}, \mathrm{Ce})(\mathrm{Y}, \mathrm{U})\left(\mathrm{Ti}, \mathrm{Fe}^{3+}\right)_{20} \mathrm{O}_{38}$. The superstructure of CuSe with a 13-fold larger $a$ translation period compared to the covel line (CuS) lattice parameter has been explained as the result of different mesh widths of Kagomé nets and tetrahedral sites of the prototypic CuS sheet structure [9]. Alternatively, this superstructure has been interpreted by Taylor \& Underwood [10] invoking additional twinning. Davidite shows the full basket of Fibonacci relations between sub-cell, cell and super-cell [11]. The true cell consists of a rhombohedral sequence of layers, formed by 12 sub-cells of hexagonal-closed packed oxygen atoms supplemented by one heavy atom at the cell origin to yield $12+1 \rightarrow 13$ ones. The super-cell is the result of twinning in the (520) plane. In contrast to this, davidite crystals without twinning show the true cell size.

Recently, a novel superstructure was observed for the photocatalyst $\mathrm{Bi}_{19} \mathrm{~S}_{27} \mathrm{Br}_{3}$ on HRTEM images with lattice spacing of $3.73 \AA$, corresponding to the interlayer spacing of the (310) plane [12].

In the meantime extended work has been undertaken to clear up the boundary lines of the bismuth sulfide halo genide pseudo-binary systems [13] [14]. According to that the stability field of bismuth sulfide iodide extends above $200^{\circ} \mathrm{C}$. Crystals can be maintained stable at room temperature for years.

The reason to revisit new/old crystal-chemical detail of the title compound is based on its suggested applicability in thin film solar cells or dye-cells due to its potentially interesting electronic properties.

In the following chapters first the result of the determination of the "averaged" structure with the original unit cell size will be discussed. From this, shortcomings of earlier interpretation attempts will become obvious, leading to strong evidence of a Fibonacci super-cell with a still fractional chemical cell content, and eventually to the formula $\mathrm{Bi}_{5-\mathrm{x}}\left(\mathrm{Bi}_{2} \mathrm{~S}_{3}\right)_{39} \mathrm{I}_{12} \mathrm{~S}$. Finally, possible ambient temperature synthesis routes and solar cell application of the compound will be highlighted.

Members of the Fibonacci numbers sequence like 1, 2, 3, 5, .., 13, ... which occurred in the morphology of crystals and during the structure determination, inspired the naming Fibonacci superstructure.

\section{Experimental}

As described long time ago [1], highly reflecting crystal needles of the title compound are formed, if $\mathrm{Bi}_{2} \mathrm{~S}_{3}$ powder is transported with iodine vapor in a partially evacuated vitreous silica ampoule from a temperature of $700^{\circ} \mathrm{C}$ to the equilibrium temperature of about $550^{\circ} \mathrm{C}$, determined through $\mathrm{T}(\Delta \mathrm{G}=0)=\Delta \mathrm{H} / \Delta \mathrm{S}$ of the underlying gas reaction involving $\mathrm{BiI}_{\mathrm{g}}$. The hexagonal crystals develop the $\{100\}$ and $\{110\}$ prisms as well as less pronounced $\{210\}$ and $\{310\}$ faces that allow looking inside their atomic structure (morphologic aspect). The hexagonal crystals with lattice parameters of a = 15.629(3) $\AA, c=4.015(1) \AA$ (see Table 1) (Cu-K $\alpha_{1}$ Guinier data) belong to the polar space group $\mathrm{P}_{3}$ (No. 173), because the centrosymmetric space group $\mathrm{P}_{3} / \mathrm{m}$, also possible due to systematically absent reflections found, could be excluded by virtue of the pyroelectric response observing qualitatively spontaneous polarization under a static temperature change. The unit cell content of two $\mathrm{Bi}_{19 / 3} \mathrm{IS}_{9}$ formula units agreed with the chemical analysis and the observed density of $D_{o b s}=6.74(4) \mathrm{Mg} \cdot \mathrm{m}^{-3}$, obviously confirming some not fully occupied metal positions; the calculated density was $D_{x}=6.76 \mathrm{Mg} \cdot \mathrm{m}^{-3}$. A super-cell could not be verified at that time.

From strong hk0 reflections, 310 and 250 respectively, which correspond to morphologically observed faces, one constructed a sub-cell with grid points that indicate the heavy atom positions projected on (001) (see Figure 1 ). In this way the $x$ and $y$ coordinates of two six-fold Bi positions have been found as multiples of $1 / 13$. We notice that the sum of $h^{2}+k^{2}+h \cdot k$ for $h=3, k=1$ gives the Fibonacci number 13. In addition, the equal intensity distribution on records with $\mathrm{l}=0,1,2$ is indicative for $\mathrm{z}$ coordinates of the heavy atoms near $1 / 4$ or $3 / 4$ respective- 


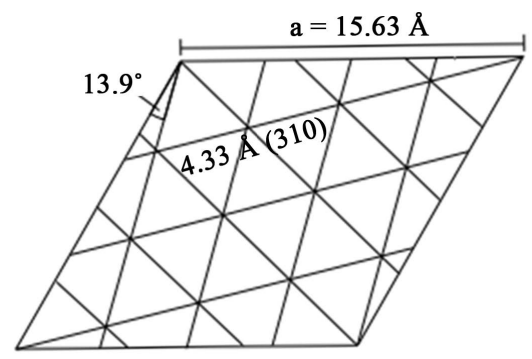

Figure 1. Sub-cell grid outlined within the projected unit-cell of the "averaged" structure representing the 13 heavy atom positions (Otto, 1965). The sub-cell is rotated by about $13.9^{\circ}$ against the unit-cell.

Table 1. Hierarchy of lattice parameters ( $\AA$ ).

\begin{tabular}{cccc}
\hline Sub-cell & $\mathrm{a} / \sqrt{ } 13$ & $4.335(1)$ & $15.629(3)$ \\
“Averaged” cell & $\mathrm{a}$ & $27.070(6)$ & $\mathrm{c}=4.018(1)$ \\
Enlarged cell & $\mathrm{a} \cdot \sqrt{ } 3$ & $56.351(9)$ \\
Super-cell & $\mathrm{a} \cdot \sqrt{ } 13$ & \\
\hline
\end{tabular}

ly. With the assumed positions for $\mathrm{Bi}(1)$ as $1 / 13,4 / 13,1 / 4$ and $\mathrm{Bi}(2)$ as 2/13, 8/13, 3/4a least squares refinement and a subsequent difference Fourier synthesis confirmed the positions of all atoms. The sub-cell concept as a tool for solving crystal structures was used in the determination of the crystal structure of $\mathrm{Pb}_{6}\left[\mathrm{Ge}_{6} \mathrm{O}_{18}\right] \cdot 2 \mathrm{H}_{2} \mathrm{O}$, too [15]. Integrated intensities from Weissenberg multiple film records, taken with $\mathrm{Cu}-\mathrm{K} \alpha$ radiation, have been thoroughly corrected according to a procedure published previously [16]. After merging symmetrically equivalent reflections at least 582 independent ones remained with Fo $>4 \sigma$ (Fo). An absorption correction for cylindrical samples [17] was made for the used prismatic crystal needle of only $12.5 \mu \mathrm{m}$ effective diameter giving $\mu \mathrm{R}$ $=0.909$. Corrected secondary extinction corresponds to a fitted mosaic domain radius of $0.452 \mu \mathrm{m}$ [18]. The structure refinement was performed with the PCSHELXL software package [19] using atomic form amplitudes for $\mathrm{Bi}^{3+}, \mathrm{S}^{2-}$ and $\mathrm{I}^{1-}$ from International Tables IV. The absolute configuration is revealed within significant sign of twinning (Flack parameterx $=0.01(10)$ ). Final reliability factors of $\mathrm{w}$ R2 $=0.076$ and R1 $=0.036$ (goodness of fit $\mathrm{S}=1.28$ ) were obtained with the residual electron density of $\Delta \rho_{\max }=1.99 \mathrm{e} / \AA^{3}, \Delta \rho_{\min }=-2.06 \mathrm{e} / \AA^{3}$ and $\Delta \rho_{\text {rms }}=0.45 \mathrm{e} / \AA^{3}$. Atom parameters and anisotropic displacement coefficients of the "averaged" structure are summarized in the Table 2 and Table 3. Table 4 gives bond lengths and calculated bond valence sums. The bond valence sums $=\Sigma \mathrm{s}_{\mathrm{i}}$ was calculated according to Brow \& Shannon [20] using $\mathrm{s}_{\mathrm{i}}=\left(\mathrm{d}_{\mathrm{i}}(\mathrm{Me}-\mathrm{S}) / \mathrm{d}_{0}\right)^{-\mathrm{N}}$ with $\mathrm{d}_{0}$ $=2.459(7) \AA, \mathrm{N}=5.3(7)[21]$.

\section{Discussion}

\subsection{Enlarged Unit Cell Option}

The peculiar unit cell content with not fully occupied atomic positions may be a sign of some disorder or caused by a larger cell. First one may consider an enlarged cell with still $\mathrm{P}_{3}$ symmetry and lattice parameters of a' = $\mathrm{a} \cdot \sqrt{3}=27.070(6) \AA$ (see Table 1 ) resulting in a space group compatible non-fractional formula of $\mathrm{Bi}_{19} \mathrm{~S}_{27} \mathrm{I}_{3}$ with $\mathrm{Z}=2$ units. In Table 5 a comparison shows the assumed site occupations with an empty 2a site and a fully occupied $2 \mathrm{~b}$ site for $\mathrm{Bi}$ (3). In the large cell there remains higher symmetry around the iodine sites and the Bi (3) 2b one, butth is should not be a serious problem. The different $\mathrm{Bi}$ (3) occupation would only slightly affect the intensity of sensitive reflections. But in the following chapter the large cell option is rejected as less plausible.

\subsection{Features of the "Averaged" Structure}

Our result of the structure determination reveals, in contrast to before published data, a splitting position for Bi (1) with unevenly distributed atomic occupation according to Table 1, but full occupation when taking the sum for $\mathrm{Bi}(1)$ and $\mathrm{Bi}(1)$ '. The Bi (1)' occupancy of 0.46 (5) per unit cell does not be pure coincidence and could 
Table 2. Fractional atomic coordinates, occupancies and isotropic or equivalent to isotropic displacement factors $\left(\AA^{2}\right)$ of the “averaged” structure.

\begin{tabular}{|c|c|c|c|c|c|c|c|c|}
\hline Atom & $\mathrm{x}$ & $\mathrm{y}$ & $\mathrm{z}$ & Site & Occupancy & 2.apfu & 26·apfu & $\mathrm{U}_{\mathrm{eq}}$ or $\mathrm{U}_{\text {iso }}$ \\
\hline $\mathrm{Bi}(1)$ & $0.29571(8)$ & $0.23991(20)$ & 0.2490 (9) & $6 c$ & $0.912(10)$ & $5.47(6)$ & 71.14 (81) & 0.0202 (3) \\
\hline Bi (1)' & $0.2872(10)$ & $0.1988(20)$ & 0.251 (17) & $6 c$ & 0.077 (8) & $0.46(5)$ & $6.00(59)$ & $0.016(7)$ \\
\hline $\mathrm{Bi}(2)$ & $0.39065(6)$ & $0.51274(6)$ & $0.7475(7)$ & $6 c$ & 0.9889 & 5.933 & 77.13 & 0.0177 (4) \\
\hline Bi (2)' & 0.3119 (55) & 0.5177 (54) & 0.700 (35) & 6c & $0.0111(30)$ & 0.067 (18) & $0.86(23)$ & $0.012^{*}$ \\
\hline $\mathrm{Bi}(3)$ & 0.008 & 0 & $0.1030(24)$ & $2 a$ & $0.1180(30)$ & 0.708 (19) & 9.20 & $0.0267(41)$ \\
\hline I & $1 / 3$ & $2 / 3$ & $0.2400(32)$ & $2 b$ & $0.2878(44)$ & $1.727(28)$ & 22.45 & $0.0179(12)$ \\
\hline S (1) & $0.1680(4)$ & 0.1837 (4) & $0.737(5)$ & $6 c$ & 1 & 6 & 78 & 0.0148 (19) \\
\hline S (2) & 0.2635 (4) & 0.3954 (4) & $0.244(6)$ & $6 c$ & 1 & 6 & 78 & $0.0148(16)$ \\
\hline S (3) & $0.4540(4)$ & $0.3880(4)$ & $0.760(5)$ & $6 c$ & 1 & 6 & 78 & 0.0157 (13) \\
\hline S (4) & $1 / 3$ & $2 / 3$ & $-0.169(56)$ & $2 b$ & $0.022(10)$ & $0.132(63)$ & $1.72(82)$ & $0.010^{*}$ \\
\hline
\end{tabular}

${ }^{*}$ Fixed value.

Table 3. Atomic displacement parameters $\left(\AA^{2}\right)$ of the "averaged” structure.

\begin{tabular}{ccccccc}
\hline Atom & $\mathrm{U}_{11}$ & $\mathrm{U}_{22}$ & $\mathrm{U}_{33}$ & $\mathrm{U}_{12}$ & $\mathrm{U}_{13}$ & $\mathrm{U}_{23}$ \\
\hline $\mathrm{Bi}(1)$ & $0.0142(5)$ & $0.0279(13)$ & $0.0198(9)$ & $0.0116(5)$ & $-0.0024(13)$ & $-0.0048(16)$ \\
$\mathrm{Bi}(2)$ & $0.0162(5)$ & $0.0159(5)$ & $0.0232(7)$ & $0.0097(3)$ & $-0.0047(12)$ & $-0.0069(13)$ \\
$\mathrm{Bi}(3)$ & $0.0149(76)$ & $0.0148(64)$ & $0.047(12)$ & $0.0109(13)$ & 0 & 0 \\
$\mathrm{I}$ & $0.0158(11)$ & $0.0158(11)$ & $0.0221(28)$ & $0.0079(5)$ & 0 & 0 \\
$\mathrm{~S}(1)^{*}$ & $0.0118(22)$ & $0.0142(22)$ & $0.0172(55)$ & $0.0055(19)$ & $0.0053(19)$ & $-0.0004(53)$ \\
$\mathrm{S}(2)$ & $0.0128(22)$ & $0.0129(22)$ & $0.0164(45)$ & $0.0047(18)$ & $0.0056(70)$ & $-0.0047(64)$ \\
$\mathrm{S}(3)$ & $0.0130(22)$ & $0.0108(21)$ & $0.0215(40)$ & $0.0046(18)$ & $0.0076(76)$ & $-0.0019(78)$ \\
\hline
\end{tabular}

"The flat ellipsoid may be due to "relaxation" effects caused by splitting of the Bi (1) position.

Table 4. Principal mean atomic displacements.

\begin{tabular}{cccc}
\hline Atom & & $\mathrm{U}\left(\AA^{2}\right)$ & 0.0122 \\
$\mathrm{Bi}(1)$ & 0.0305 & 0.0177 & 0.0114 \\
$\mathrm{Bi}(2)$ & 0.0278 & 0.0139 & 0.0131 \\
$\mathrm{Bi}(3)^{*}$ & 0.0468 & 0.0199 & 0.0158 \\
$\mathrm{I}$ & 0.0221 & 0.0158 & 0.0019 \\
$\mathrm{~S}(1)$ & 0.0282 & 0.0144 & 0.0059 \\
$\mathrm{~S}(2)$ & 0.0267 & 0.0117 & 0.0084 \\
$\mathrm{~S}(3)$ & 0.0265 & 0.0121 & \\
\hline
\end{tabular}

*Off-center position (see Table 2). 
Table 5. Bond lengths in $(\AA)$ and bond valence sums s for coordination [k].

\begin{tabular}{|c|c|c|c|c|c|}
\hline \multirow{2}{*}{ Atoms } & \multirow{2}{*}{$\mathrm{Bi}(1)$} & \multirow{2}{*}{$\mathrm{Bi}(1)^{\prime}$} & \multirow{2}{*}{$\mathrm{Bi}(2)$} & \multicolumn{2}{|c|}{$\mathrm{Bi}(3)$} \\
\hline & & & & Center & Off-Center \\
\hline S (1) & $\begin{array}{c}2.617(16) \\
2.691(15) \\
3.036(6)\end{array}$ & $\begin{array}{l}2.487 \text { (27) } \\
2.626 \text { (58) } \\
2.714 \text { (58) }\end{array}$ & & $2.811(7) \times 3$ & $\begin{array}{l}2.687(7) \\
2.865(7) \\
2.881(7)\end{array}$ \\
\hline S (2) & $\begin{array}{l}2.718(6) \\
3.443(8) \\
3.467(8)\end{array}$ & $\begin{array}{l}3.107(49) \\
3.143(49) \\
3.274(29)\end{array}$ & $\begin{array}{l}2.767(17) \\
2.786(18)\end{array}$ & $3.127(12) \times 3$ & $\begin{array}{l}3.065(12) \\
3.080(12) \\
3.237(12)\end{array}$ \\
\hline S (3) & $\begin{array}{l}3.101(14) \\
3.157(14)\end{array}$ & $\begin{array}{l}3.424(50) \\
3.466(50)\end{array}$ & $\begin{array}{c}2.593(5) \\
2.895(14) \\
2.963(16)\end{array}$ & $3.755(17) \times 3$ & $\begin{array}{l}3.704(17) \\
3.716(17) \\
3.846(17)\end{array}$ \\
\hline I (1) & & & $\begin{array}{l}3.560(8) \\
3.593(8)\end{array}$ & & \\
\hline orS $(4)^{*}$ & & & 2.978 (25) & & \\
\hline $\mathrm{s}[\mathrm{k}]$ & $\begin{array}{l}2.81[6] \\
3.14[8]\end{array}$ & $\begin{array}{l}3.03[6] \\
3.36[8]\end{array}$ & $\begin{array}{l}2.86[7] \\
2.97[6]^{*}\end{array}$ & & \\
\hline
\end{tabular}

advise to enlarge the unit cell. If one multiplies this occupancy by 13, then 6 atoms would result. This may evidence a possible super-cell extending in the ab plane. Further facts will confirm this idea. The determined structure of the smaller cell is considered as "averaged" structure with all super-cell atoms projected onto it, thus showing partly occupied atomic sites as well as split positions, "relaxation" effects of the surrounding atoms and anomalous atomic displacement, which ends up in larger statistical errors of the atomic coordinates. Less likely there exists statistical disorder, for instance introduced by lamellae of "strained" BiSI, because its unit cell shows metric relationship to that of $\mathrm{Bi}_{19 / 3} \mathrm{IS}_{9}$ [1].

A projection of the "averaged" structure on (001) is depicted in Figure 2. As already described by Miehe \& Kupčik [3], $\left(\mathrm{Bi}_{4} \mathrm{~S}_{6}\right)_{\infty}$ ribbons extend infinitely along $c$ and are linked via longer bonds by $\mathrm{Bi}$ (3). This molecular composite forms an angle of about $14^{\circ}$ to the a axis, which is the angle between sub-cell and actual unit-cell (see Figure 1). Bi (3) on the 2a site shows reduced occupancy because two big Bi atoms cannot lie one above the other within the short $c$ translation period [3]. But the assumed occupancy with only one atom is further reduced (Table 1) allowing space for strong thermal or lateral displacement along the [001] channel, which is indeed observed; therms displacement amplitude in this direction is large with $0.27 \AA . \mathrm{Bi}^{3+}$ belongs to a group of polar cations by virtue of its lone electron pair. The lone electron pair of $\mathrm{Bi}(3)$ points in [001] direction with three $\mathrm{S}^{2-}$ ligands closer to and three other ones further away. It mainly contributes to the induced lattice polarization and anharmonicity effects of the acentric crystals. The calculated bond valence sum of $\mathrm{Bi}$ (3) amounts to s $=2.94$, if one includes three more distant S (3) ligands of the coordination sphere (Table 5). On the other hand, large displacement also perpendicular to can be caused by a threefold off-center split position, equivalent to the Bi split position of the acentric $\mathrm{Pb}_{3} \mathrm{Bi}_{2}\left(\mathrm{GeO}_{4}\right)_{3}$ apatite triplet domain structure [22]. The off-center position is simulated with a slight shift of the $\mathrm{x}$-coordinate, resulting in a reduced thermal displacement (Table 4). But this problem is more elegantly solved applying the super-cell concept below. As a consequence of the partly vacant $\mathrm{Bi}$ (3) site, in terms of balanced cation to anion charges, the iodine atoms on the twofold $1 / 3,2 / 3$, z site, being coordinated by six $\mathrm{Bi}(2)$ atoms, reveal a reduced occupancy and obviously a partial substitution of sulfur $\mathrm{S}$ (4). The short mean distance between $\mathrm{I}^{1-}$ of $\mathrm{c}=4.018 \AA$ results in an extremely small ion radius of $2.009 \AA$ for six-fold coordination. The almost equal c lattice parameters for bismuth sulfide iodide respectively bromideindicate that the major anion species causes this distance and that the large anion minor species is adapted to this spacing by virtue of some vacant positions. For the physical properties it may be important that the formation of some $\mathrm{I}_{2}{ }^{1-}$ dimer centers consuming less space is quite likely (Table 6).

Published displacement coefficients for Bi (3) of the isotypic bismuth sulfide bromide [6] seem to be nonrealistic. Insufficiently low site occupation may be the reason for that result. The strong correlation of the $\mathrm{Bi}(3)$ site occupation with displacement coefficients is quite evident.

If one select for the "averaged" structure the space group P3 with the general site multiplicity of 3 instead of 6 and multiplicity of 1 for the 0,0 , z site, then a twist of the atoms around the c axis is allowed, but the Bi (1)' 


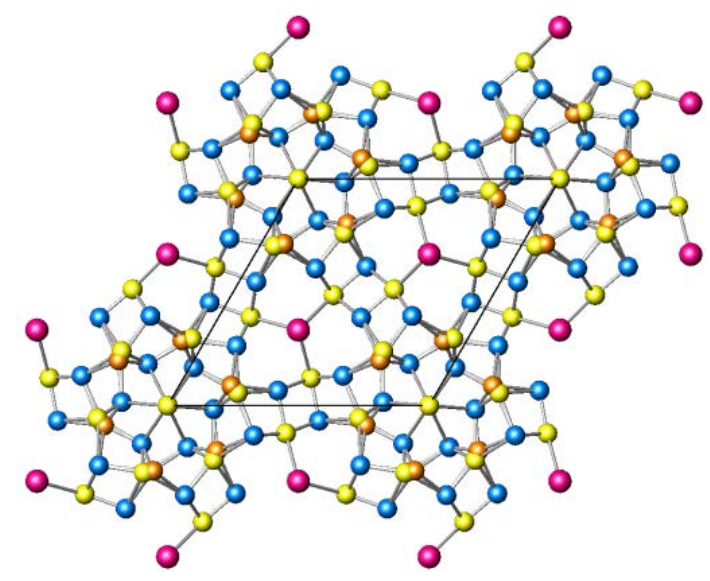

Figure 2. The "averaged" structure of $\mathrm{Bi}_{5-x}\left(\mathrm{Bi}_{2} \mathrm{~S}_{3}\right)_{39} \mathrm{I}_{12} \mathrm{~S}$ projected down [001]. Bi yellow, Bi (1)' split position orange, $\mathrm{S}$ blue and I pink. The $\mathrm{Bi}_{4} \mathrm{~S}_{6}$ ribbon is clearly visible with a $13.9^{\circ}$ offset from the short cell diagonal.

Table 6. Proposed site occupation of original cell, enlarged one and super-cell, always space group $\mathrm{P}_{3}$.

\begin{tabular}{|c|c|c|c|c|c|c|}
\hline Lattice parameter & \multicolumn{2}{|c|}{$\mathrm{a}=15.629(3) \AA$} & \multicolumn{2}{|c|}{$a^{\prime}=a \cdot \sqrt{ } 3=27.070(9) \AA$} & \multicolumn{2}{|c|}{$\mathrm{a}^{\prime}=\mathrm{a} \cdot \sqrt{ } 13=56.351(9) \AA$} \\
\hline Atoms & Site & Occupation & Site & Occupation & Site & Occupation \\
\hline $\mathrm{Bi}(1)$ & \multirow{2}{*}{$6 c$} & \multirow{2}{*}{1} & \multirow{2}{*}{$3 \times 6 c$} & \multirow{2}{*}{$3 \times 1$} & $12 \times 6 c$ & $12 \times 0.99$ \\
\hline $\mathrm{Bi}(1)^{\prime}$ & & & & & $6 c$ & 1 \\
\hline $\mathrm{Bi}(2)+\mathrm{Bi}(2)^{\prime}$ & $6 c$ & 1 & $3 \times 6 c$ & $3 \times 1$ & $13 \times 6 c$ & $13 \times 1$ \\
\hline \multirow{2}{*}{$\mathrm{Bi}(3)$} & \multirow{2}{*}{$2 \mathrm{a}$} & \multirow{2}{*}{$1 / 3$} & $2 \mathrm{a}$ & 0 & 2a & 0 \\
\hline & & & $2 \mathrm{~b}$ & 1 & $12 \times 6 c$ & $12 \times 0.767$ \\
\hline S (1) & $6 c$ & 1 & $3 \times 6 c$ & $3 \times 1$ & $13 \times 6 c$ & 1 \\
\hline S (2) & $6 c$ & 1 & $3 \times 6 c$ & $3 \times 1$ & $13 \times 6 c$ & 1 \\
\hline S (3) & $6 c$ & 1 & $3 \times 6 c$ & $3 \times 1$ & $13 \times 6 c$ & 1 \\
\hline S (4) & & & & & $2 b$ & 0.86 \\
\hline I & $2 b$ & 1 & $6 c$ & 1 & $12 \times 6 c$ & $12 \times 0.936$ \\
\hline$Z=2$ & \multicolumn{2}{|c|}{$\mathrm{Bi}_{19 / 3} \mathrm{~S}_{9} \mathrm{I}$} & \multicolumn{2}{|c|}{$\mathrm{Bi}_{19} \mathrm{~S}_{27} \mathrm{I}_{3}$} & \multicolumn{2}{|c|}{$\mathrm{Bi}_{5-\mathrm{x}}\left(\mathrm{Bi}_{2} \mathrm{~S}_{3}\right)_{39} \mathrm{I}_{12} \mathrm{~S}$} \\
\hline
\end{tabular}

split site remained as well as splitting of the $\mathrm{Bi}(3)$ site at 0,0 , z. The intensity of 001 reflections with uneven $\mathrm{l}$ would be hardly observable in order to decide between both space groups.

\subsection{Concept of a Superstructure}

More suitable is to mold the determined Bi (1)', Bi (3) and I occupancies in a consistent structure model, because the formerly assumed unit-cell contribution of $2 / 3 \mathrm{Bi}$ (3) $\mathrm{I}_{3}$ is obviously incorrect. Together with the result for the $\mathrm{Bi}(1)^{\prime}$ split position, strong evidence is found for a Fibonacci super-cell with enlarged lattice parameters of $\mathrm{a}^{\prime}=\sqrt{ } 13 \cdot \mathrm{a}=56.35 \AA$ (Figure 3 ). The avalanche of lattice parameters for sub-cell, cell and super-cell is surveyed in Table 1 . Symmetry elements of space group $\mathrm{P}_{3}$ are retained in the super-cell, together with a lot of pseudo-symmetry elements limiting possible reflections. There still is a twofold position at 0,0 , z. Considering this 2a position unoccupied, Bi (3) would occupy in the super-cell 2 six-fold sites without restriction in coordinates or displacement parameters with a partial occupation of 9.20/12 $=0.767$. It may be stressed that in this arrangement the basis plane dipole moment of $\mathrm{Bi}(3)$ will be compensated to secure the structural stability, only the remaining c component of that moment will contribute to polarity. Also off-center position and large atomic 


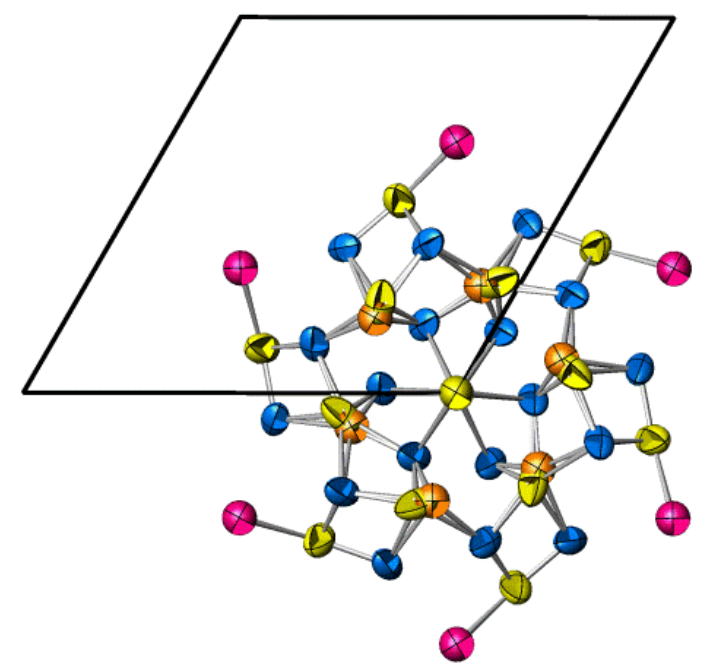

Figure 3. Drawing of the displacement ellipsoids of the "averaged" structure, projected down [001]. The color of the atoms is chosen as in Figure 2.

displacement of $\mathrm{Bi}(3)$ as found in the "averaged" structure fit can be explained with this super-cell site occupation. Around the unoccupied channel along $0,0, \mathrm{z}$ the six Bi (1)' split atoms may be arranged giving a very plausible structural detail, depicted in Figure 4. If the twofold position is considered occupied, then an even larger cell would be required and so on (devils staircase), in a way remembering at a kind of self-similarity as in fractals and quasi-crystals. But there is no need for such $\mathrm{Bi}$ (3) occupation. In a similar way the formerly twofold position for iodine splits in two six-fold positions and the twofold one at 1/3, 2/3, z. Again evidence is given for a separate occupation of the twofold 2b site with S (4) (see Figure 5) and the six-fold ones with I, but both sites show some vacancies. The coordination of $\mathrm{Bi}(2)$ with $\mathrm{S}(4)$ would be sixfold, giving a bond valence sum of $\mathrm{s}=$ 2.97. The questioned split position Bi (2)' of the "average" structure, contributing only $0.0126 \times 2 \times 13=0.33$ atoms to the super-cell content, is not interpreted further. In conclusion, asuper-cell with parameters a' and c contains $\mathrm{Z}=2$ formula units of $\mathrm{Bi}_{4.6}\left(\mathrm{Bi}_{2} \mathrm{~S}_{3}\right)_{39} \mathrm{I}_{11.23} \mathrm{~S}_{0.86}$ and leads to a calculated density of $\mathrm{D}_{\mathrm{x}}=6.73 \mathrm{~g} \cdot \mathrm{cm}^{-3}$. The charge content is balanced, if some vacancies of $\mathrm{Bi}(1)$ are included (see Table 2). The idealized formula is given as $\mathrm{Bi}_{5-x}\left(\mathrm{Bi}_{2} \mathrm{~S}_{3}\right)_{39} \mathrm{I}_{12} \mathrm{~S}$. Returning to the space group $\mathrm{P} 3$, one could distribute $2 \cdot 4.6 \approx 9 \mathrm{Bi}$ (3) atoms place one threefold sites, leaving some more empty ones.

The complex superstructure was not individually depicted, because the relation between super-cell and "averaged" cell is the same as that between "averaged" cell and sub-cell, shown in Figure 1.

The limited data set measured with $\mathrm{Cu}$ radiation is unsuitable to solve the problem in more detail. In future work it is recommended to seek for even the weakest diffraction evidence of a super-cell within the $\mathrm{a}^{*} \mathrm{~b}^{*}$ plane of the reciprocal lattice and for twinning that may complicate the matter.

\subsection{Superstructure of Isotypic $\mathrm{Bi}_{19} \mathrm{~S}_{27} \mathrm{Br}_{3}$ Seen on HRTEM Images}

Recently, Deng et al. [12] published high-resolution TEM images of isotypic $\mathrm{Bi}_{19} \mathrm{~S}_{27} \mathrm{Br}_{3}$ grown by a microwaveassisted aqueous synthesis route. These images show $3.73 \AA$ thick slabs corresponding to the (310) spacing. According to Figure 1 and Figure 2, this plane is most densely packed and runs along the $\mathrm{Bi}_{2} \mathrm{~S}_{3}$ ribbons. The identity period in the (310) plane is a lattice vector of length $\mathrm{a}^{\prime}=\mathrm{a} \cdot \sqrt{ }\left(\mathrm{h}^{2}+\mathrm{k}^{2}+\mathrm{h} \cdot \mathrm{k}\right)=15.546 \times \sqrt{13}=56.05 \AA$, which is exactly the proposed Fibonacci superstructure lattice parameter.

Supported by vacant atomic positions, the (310) slabs may be able to glide against each other leading to the observed superstructure. Figure 1 also shows that the split positions of $\mathrm{Bi}_{5-\mathrm{x}}\left(\mathrm{Bi}_{2} \mathrm{~S}_{3}\right)_{39} \mathrm{I}_{12} \mathrm{~S}$ are accumulated in this slabs. An impressive example for the elimination of vacancies by way of chemical twinning is the cubic solid solution of $\mathrm{Bi}_{2} \mathrm{~S}_{3}\left(\mathrm{Bi}_{2 / 31 / 3} \mathrm{~S}\right)$ in $\mathrm{PbS}$ that can accumulate very much vacant metal sites. This less dense structure transforms finally by unit-cell twinning along $(311)_{\mathrm{PbS}}$ to orthorhombic $6 \mathrm{PbS} \cdot \mathrm{Bi}_{2} \mathrm{~S}_{3}$ (heyrovskyite) as the first member of a homologous series of crystal structures, consisting of twinned PbS slabs [1] [2]. [12].

Superstructure nano-slabs of $\mathrm{Bi}_{19} \mathrm{~S}_{27} \mathrm{Br}_{3}$ (still using this formula) show excellent photo-catalytic properties 


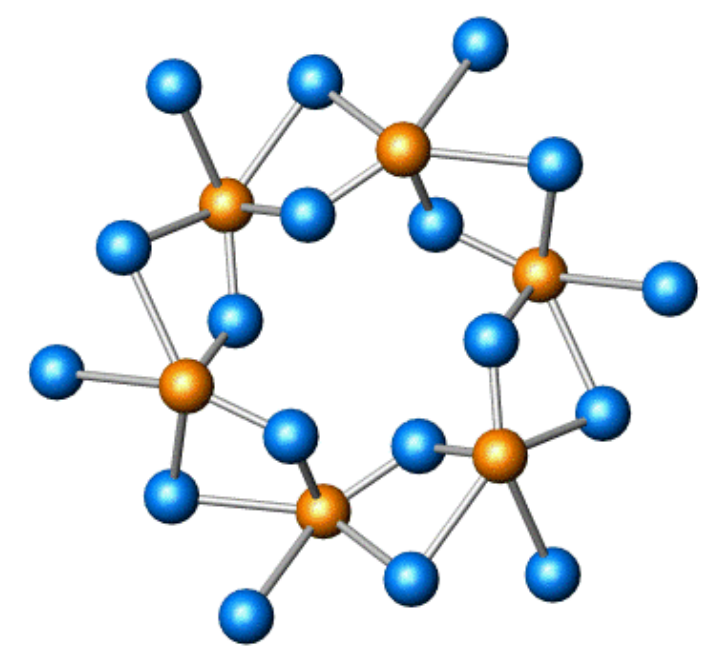

Figure 4. Projected superstructure detail around the empty channel along $0,0, \mathrm{z}$. Split position $\mathrm{Bi}(1)^{\prime}$ brownish, $\mathrm{S}$ blue.

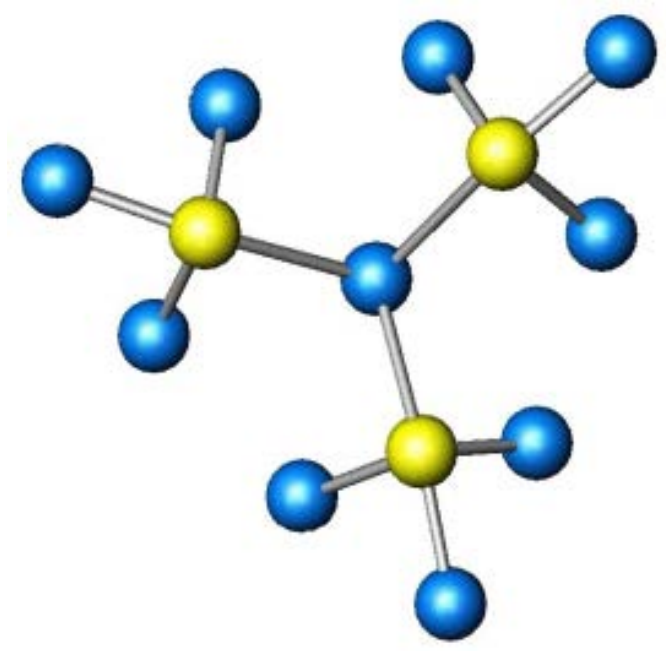

Figure 5. Projected superstructure detail around the $2 \mathrm{~b}$ position $(1 / 3,2 / 3, \mathrm{z})$, occupied with S (4). Bi (2) (yellow) coordinated by 6 sulfur atoms (blue).

If one pursues this idea, then a compound of the $\mathrm{PbS}-\mathrm{Bi}_{2} \mathrm{~S}_{3}$ homologous series, besides the title compound, is still overlooked allowing for such property. In the compound PbS· $2 \mathrm{Bi}_{2} \mathrm{~S}_{3}$, pure or less iodine substituted, the slabs are extremely weak bond by van der Waals interaction and suffer from severe disorder. If you fans out the layers, a very strong supercharging is observed on the large surface as prerequisites for photo-catalytic activity.

\section{Synthesis Routes and Application Remarks}

The crystals are stable under ambient conditions, especially stable against humidity, and contain less toxic elements as prerequisites for any application. Therefore, ambient temperature synthesis routes such as co-precipitation from solution are under investigation, in case the compound is considered as alternative, environmentally benign solar energy harvesting material in thin film solar cells or dye-sensitized ones [23]. The suggested energy gap of $\mathrm{E}_{\mathrm{g}}=1.6 \mathrm{eV}$ is lying between the indirectly allowed band gap of photo-conducting and ferroelectric BiSI, reported as $\mathrm{E}_{\mathrm{g}}=1.57 \mathrm{eV}$ [24] [25] [26], and $\mathrm{E}_{\mathrm{g}}=1.69 \mathrm{eV}$ of $\mathrm{Bi}_{2} \mathrm{~S}_{3}$ [27]. For comparison, methyl ammonium lead iodide $\left(\mathrm{MAPbI}_{3}\right)$ has a gap of $\mathrm{E}_{\mathrm{g}}=1.55 \mathrm{eV}$. Today, this toxic organic-inorganic perovskite, first synthesized by Weber [28], and since 2009 applied in "dye" solar cells, reaches today a solar efficiency of about 20\% [29] and emits light as OILED, when reversely used under voltage [30]-[32]. 
The title compound belongs to the family of n-type semiconductors. The high refractivity index, roughly estimated as $n \approx 2.8$ by applying the Moss relation $\left(n^{4} E_{g}=95 \mathrm{eV}\right)$ [33], results in small effective masses and enhanced born charges, favoring effective carrier transport properties. The carrier life time as a dominant factor for an effective solar cell will be affected by iodine and bismuth vacancies suggesting deep charge-state transition levels within the complex band gap. As in the case of $\mathrm{MAPbI}_{3}$ [34], some energetically favorable dimers of Bi and I may be formed along [001]. When the polar axis of the nano-sized needles can be aligned normal to the back electrode, charge separation of sunlight induced carriers should be supported. So the compound may offer a basket of physically interesting properties.

Simple techniques have been proposed to grow perfectly oriented crystalline layers. For example, copper alloyed with some Au, thermally vapor deposited on a freshly cleaved mica sheet with its Kagomé surface, is ideally adapted to act as substrate for epitaxial deposition of (001) layers or nano-rod carpets of the hexagonal bismuth sulfide iodide. The lattice parameter of cubic $\mathrm{Cu}_{0.848} \mathrm{Au}_{0.152}$ is $3.6837 \AA$ giving a distance of $\mathrm{d}_{(111)}=$ $2.6048 \AA$; the a parameter of the bismuth sulfide iodidevery well complies with a multiple of this distance: $\mathrm{a}=$ $6 \cdot d_{(111)}$ (alloy). More important, the ratio of the sub-cell length $\left(a_{\text {sub }}=4.335 \AA\right.$ ) to $d_{(111)}$ (alloy) yields exactly $5 / 3$ and promises success. Another synthesis route may be found insono-chemical preparation from a gel in alcoholic solution, because acoustic cavitation produces intense local heating and enhanced reactivity. This method has recently been applied in the synthesis of chemically similar compounds such as SbS I [35].

Dealing now with solar cell construction made from bismuth sulfide iodide. When the copper bearing alloy is annealed in iodine vapor before epitaxial deposition of bismuth sulfide iodide, then a smart hole conducting layer may be created between photoconductor and back electrode due to the formation of (111) oriented sphalerite-type $\mathrm{CuI}$ with its favorable band gap of about $3.1 \mathrm{eV}$, dielectric constant of $\varepsilon=6.5$, and small effective hole mass of $m_{h} *=0.38$ [36]-[38]. The Cu-I distance of $2.62 \AA$ would agree very well with $\mathrm{d}_{(111)}$ of an alloy of composition $\mathrm{Cu}_{0.805} \mathrm{Au}_{0.795}$ allowing still for subsequent perfectly epitaxial growth of the bismuth sulfide iodide film onto CuI. The remaining gold at the mica surface once copper is transformed into iodide will accumulate to nanoclusters due to its high surface mobility. As an optical meta-material these clusters do not lessen the transparency, but even increase the conductivity effectively cooperating with CuI as back electrode, transporting light-induced hole carriers away.

On the other hand one does not need a metallic back electrode at all but uses directly CuI because of its sufficiently high hole conductivity. So CuI can be prepared by evaporating pure copper onto freshly cleaved muscovite mica in vacuum and then transformed into CuI by vapor from a weak solution of iodine.

Because muscovite mica is a less disposable natural material, supporting the deposition of highly oriented CuI transparent films for research purposes, it may in future be replaces by transparent and less costly substrates. Mercapto-silane surface activated fused silica has been reported to strongly bind thin gold films deposited by ebeam or thermal evaporation [39]. The deposition of a copper bearing alloy discussed before may bind the better at the activated silica surface. Evading vacuum technology, a solution processed deposition route was recommended for substrates like fused silica, using acetonitrile solved CuI in combination with a stabilizer like tetramethyleethylenediamine (TMED) [40].

If both surfaces of the silica substrate being CuI coated, then the centerpiece of a completely inorganic twin solar cell is realized. Figure 6 shows the layer structure of such semi-transparent solar cell based on hexagonal bismuth sulfide iodide, but as a twin cell device with enhanced solar efficiency and low environmental footprint. This construction is even advisable for toxic perovskite solar cells and may considerably enhance the efficiency over that of a recently realized perovskite-silicon solar tandem cell [41].

\section{Conclusions}

New evidence was collected for the existence of hexagonal bismuth sulfide iodide in a superstructure, characterized by the idealized formula $\mathrm{Bi}_{5-\mathrm{x}}\left(\mathrm{Bi}_{2} \mathrm{~S}_{3}\right)_{39} \mathrm{I}_{12} \mathrm{~S}, \mathrm{Z}=2$, space group $\mathrm{P}_{3}$, enlarged lattice parameter of a' = $\sqrt{13} \cdot \mathrm{a}=56.351(9) \AA$ in comparison to the still used "averaged" structure, and c' = c = 4.018(1) $\AA$. The superstructure concept guarantees more structural stability due to compensation of the basal plane dipole momentum of the Bi lone electron pairs.

Appropriate methods such as atomic force microscopy (AFM), high-resolution transmission electron microscopy (HRTEM) or diffraction experiments with synchrotron radiation will help to further clarify structural details. Possible variation of the chemical composition should be investigated, too. 


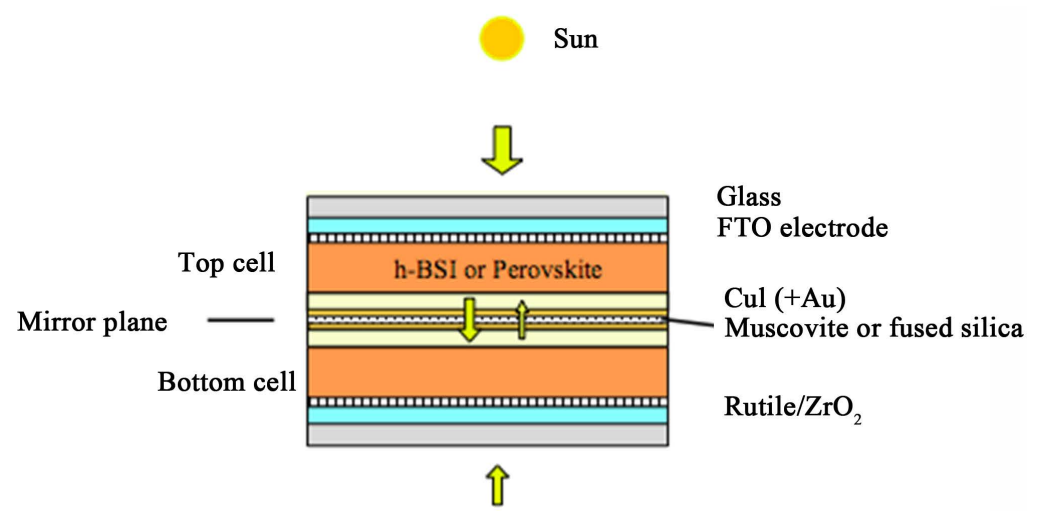

Figure 6. Schema of a twin solar cell device. Intensities of luminous fluxes are shown by yellow arrows, (h-BSI means hexagonal Bismuth Sulfide Iodide).

Because the pyroelectric effect is able to enhance charge separation of light induced excitons in semiconductors, the pyroelectric title compound with its suitable energy gap is a candidate for photovoltaic respectively photocatalytic applications and should be further examined for details of such properties, especially light-induced changes of the dipole momentum and the existence of a ferroelectric phase transition. The influence of empty channels down [001] and anyway of the unit cell inflation on the band structure and energy gap is of partial interest.

Finally, fast progress in the construction of a completely inorganic and environmental benign thin film twin solar cell device is desirable, using c-axis oriented nano-rod bismuth sulfide iodide films as light harvesting layers, epitaxially grown onto (111) oriented CuI hole conducting layers, which were in turn deposited on both sides of a transparent substrate.

\section{Acknowledgements}

The author wishes to thank Prof. Dr. R. B. Heimann for critical reading of the manuscript.

\section{References}

[1] Otto, H.H. (1965) Zur Kristallchemie Synthetischer Blei-Wismut-Spießglanze. Diploma Thesis TU Berlin.

[2] Otto, H.H. and Strunz, H. (1968) Zur Kristallchemie Synthetischer Blei-Wismut-Spießglanze. Neues Jahrbuch Für Mineralogie Abhandlungen, 108, 1-19.

[3] Miehe, G. and Kupčik, V. (1971) Die Kristallstruktur des $\mathrm{Bi}\left(\mathrm{Bi}_{2} \mathrm{~S}_{3}\right)_{9} \mathrm{I}_{3}$. Naturwissenschaften, 58, 219. http://dx.doi.org/10.1007/BF00591851

[4] Krämer, V. (1973) Crystal Data on Bismuth Sulphide Bromide. Journal of Applied Crystallography, 6, 499. http://dx.doi.org/10.1107/S0021889873009349

[5] Krämer, V. (1974) Synthesis and Crystal Data of the Bismuth Sulphide Chloride $\mathrm{Bi}_{19} \mathrm{~S}_{27} \mathrm{Cl}_{3}$. Zeitschrift für Naturforschung, 29b, 688-689.

[6] Mariolakos, K. (1976) The Crystal Structure of $\mathrm{Bi}_{(}\left(\mathrm{Bi}_{2} \mathrm{~S}_{3}\right)_{9} \mathrm{Br}_{3}$. Acta Crystallographica, B22, 1947-1949. http://dx.doi.org/10.1107/S0567740876006833

[7] Lippmann, F. (1961) Benstonit, $\mathrm{Ca}_{7} \mathrm{Ba}_{6}\left(\mathrm{CO}_{3}\right)_{13}$, Ein Neues Mineral. Naturwissenschaften, 48, 550-551. http://dx.doi.org/10.1007/BF00639159

[8] Rouse, R.C. and Peacor, D.R. (1968) The Relationship between Senaite, Magnetoplumbite, and Davidite. Americal Mineralogist, 53, 869-879.

[9] Lippmann, F. (1962) Zur Deutung der Überstruktur des Klockmannits, CuSe. Neues Jahrbuchfür Mineralogie Monatshefte, 99-105.

[10] Taylor, C.A. and Underwood, F.A. (1960) A Twinning Interpretation of "Superlattice” Reflections in X-Ray Photographs of Synthetic Klockmannite. Acta Crystallographica, 13, 361-362. http://dx.doi.org/10.1107/S0365110X60000868

[11] Contag, B. (1962) Zur Kristallchemie von Davidit. Doctoral Thesis, TU, Berlin.

[12] Deng, C., Guan, H. and Tian, X. (2013) Novel $\mathrm{Bi}_{19} \mathrm{~S}_{27} \mathrm{Br}_{3}$ Superstructures: Facile Microwave-Assisted Aqueous Syn- 
thesis and Their Visible Light Photocatalytic Performance. Materials Letters, 108, 17-20. http://dx.doi.org/10.1016/j.matlet.2013.06.078

[13] Oppermann, H. and Petasch, U. (2003) Zu den pseudobinären Zustandssystemen $\mathrm{Bi}_{2} \mathrm{Ch}_{2}-\mathrm{BiX}_{3}$ und den ternären Phasen auf diesen Schnitten (Ch = S, Se, Te; X = Cl, Br, I), I: Bismutsulfidhalogenide. Zeitschriftfür Naturforschung, 58b, 725-740.

[14] Aliev, Z.S., Musayeva, S.S., Jafarli, F.Y., Amiraslanov, I.R., Shevelkov, A.V. and Babanly, M.B. (2014) The Phase Equilibria in the Bi-S-I Ternary System and Thermodynamic Properties of the BiSI and $\mathrm{Bi}_{19} \mathrm{~S}_{27} \mathrm{I}_{3}$ Ternary Compounds. Journal of Alloys and Compounds, 610, 522-528. http://dx.doi.org/10.1016/j.jallcom.2014.05.015

[15] Otto, H.H. and Brandt, H.J. (1996) Crystal Structure of $\mathrm{Pb}_{6}\left[\mathrm{Ge}_{6} \mathrm{O}_{18}\right] \cdot 2 \mathrm{H}_{2} \mathrm{O}$, a Lead Cyclo-Germanate Similar to the Mineral Dioptase. European Journal of Mineralogy, 8, 301-310. http://dx.doi.org/10.1127/ejm/8/2/0301

[16] Otto, H.H. (1975) Die Kristallstruktur des Fleischerits, $\mathrm{Pb}_{3} \mathrm{Ge}\left[(\mathrm{OH})_{6} \mid\left(\mathrm{SO}_{4}\right)_{2}\right] \cdot 3 \mathrm{H}_{2} \mathrm{O}$, sowie kristall-chemische Untersuchungen an isotypen Verbindungen. Neues Jahrbuch für Mineralogie Abhandlungen, 123, 160-190.

[17] Weber, K. (1967) Neue Absorptionsfaktortafeln für den Kreiszylinder. Acta Crystallographica, 23, 720-725. http://dx.doi.org/10.1107/S0365110X67003585

[18] Zachariasen, W.H. (1967) A General Theory of X-Ray Diffraction in Crystals. Acta Crystallographica, 23, 558-564. http://dx.doi.org/10.1107/S0365110X67003202

[19] Sheldrick, G. (1993) PCSHELXL Manual. Universität Göttingen, Göttingen.

[20] Brown, I.D. and Shannon, R.D. (1973) Empirical Bond-Strength-Bond-Length Curves for Oxides. Acta Crystallographica, A29, 266-282. http://dx.doi.org/10.1107/S0567739473000689

[21] Otto, H.H. (1984) Neue Erkenntnisse über die Verbindungen des Systems $\mathrm{PbS}_{-} \mathrm{Bi}_{2} \mathrm{~S}_{3}$ (und verwandte Verbindungen). Zeitschrift der Förderer des Bergbaus und des Hüttenwesens an der TU Berlin, 18, 1-6.

[22] Otto, H.H. (2015) Crystal and Domain Structure of Acentric $\mathrm{Pb}_{3} \mathrm{Bi}_{2}\left(\mathrm{GeO}_{4}\right)_{3}$ Apatite. Journal of Applied Crystallography, Submitted.

[23] Grätzel, M. (2001) Photochemical Cells. Nature, 414, 338-344. http://dx.doi.org/10.1038/35104607

[24] Nitsche, R., Roetschi, H. and Wild, P. (1964) New Ferroelectric V-VI-VII Compounds of the SbSI Type. Applied Physics Letters, 4, 210-211. http://dx.doi.org/10.1063/1.1753944

[25] Sasaki, Y. (1965) Photoconductivity of a Ferroelectric Photoconductor BiSI. Japanese Journal of Applied Physics, 4, 614-615. http://dx.doi.org/10.1143/JJAP.4.614

[26] Audzijonis, A., Žaltauskas, R., Sereika, R., Žigas, L. and Réza, A. (2010) Electronic Structure and Optical Properties of BiSI Crystals. Journal of Physics and Chemistry of Solids, 71, 884-891. http://dx.doi.org/10.1016/j.jpcs.2010.03.042

[27] Medles, M., Benramdane, N., Bouzidi, A., Nakrela, A., Tabet-Derraz, H., Kebbab, Z., Mathieu, C., Khelifa, B. and Desfeux, R. (2006) Optical and Electrical Properties of $\mathrm{Bi}_{2} \mathrm{~S}_{3}$ Films Deposited by Spray Pyrolysis. Thin Solid Films, 497, 58-64. http://dx.doi.org/10.1016/j.tsf.2005.09.186

[28] Weber, D. (1978) $\mathrm{CH}_{3} \mathrm{NH}_{2} \mathrm{PbX}_{3}$, ein $\mathrm{Pb}(\mathrm{II})$-System mit kubischer Perowskitstruktur. Zeitschrift für Naturforschung, 33b, 1443-1445.

[29] Jeon, N.J., Noh, J.H., Yang, W.S., Kim, Y.C., Ryu, S., Seo, J.S. and Seok, S.H. (2015) Compositional Engineering of Perovskite Materials for High-Performance Solar Cells. Nature, 517, 476-480. http://dx.doi.org/10.1038/nature14133

[30] Hattori, T., Taira, T., Era, M., Tsutsui, T. and Saito, S. (1996) Highly Efficient Electroluminescence from a Heterostructure Device Combined with Emissive Layered-Perovskite and an Electron-Transporting Organic Compound. Chemical Physics Letters, 254, 103-108. http://dx.doi.org/10.1016/0009-2614(96)00310-7

[31] Chondroudis, K. and Mitzi, D.B. (1999) Electroluminescence from an Organic-Inorganic Perovskite Incorporating a Quaterthiophene Dye within Lead Halide Perovskite Layers. Chemistry of Materials, 11, 3028-3030. http://dx.doi.org/10.1021/cm990561t

[32] Tan, Z.-K., Moghaddam, R.S., Lai, M.L., Docampo, D., Higler, R., Deschler, F., Price, M., Sadhanala, A., Pazos, L.M., Credgington, D., Hanusch, F., Bein, T., Snaith, H.J. and Friend, R.H. (2014) Bright Light-Emitting Diodes Based on Organometal Halide Perovskite. Nature Nanotechnology, 9, 687-692. http://dx.doi.org/10.1038/nnano.2014.149

[33] Moss, T.S. (1985) Relation between Refractive Index and Energy Gap of Semiconductors. Physica Status Solidi (b), 131, 415-427. http://dx.doi.org/10.1002/pssb.2221310202

[34] Agiorgousis, M.L., Su, Y.Y., Zeng, H. and Zhang, S. (2014) Strong Covalency-Induced Recombination Centers in Perovskite Solar Cell Material $\mathrm{CH}_{3} \mathrm{NH}_{3} \mathrm{PbI}_{3}$. Journal of the American Chemical Society, 136, 14570-14575. http://dx.doi.org/10.1021/ja5079305

[35] Nowak, M., Talik, E., Szperlich, P. and Stróz, D. (2009) XPS Analysis of Sonochemical Prepared SbSI Ethanogel. Applied Surface Sciences, 255, 7689-7694. http://dx.doi.org/10.1016/j.apsusc.2009.04.138 
[36] Zhu, J., Pandey, R. and Gu, M. (2012) The Phase Transition and Elastic and Optical Properties of Polymorphs of CuI. Journal of Physics: Condensed Matter, 24, Article ID: 475503.

[37] Haroldson, R., Olds, Z., Cook, A.B. and Zakhidov, A. (2015) Hybrid Perovskite Solar Cells with Copper Iodide as Hole Transportlayer. Bulletin of the American Physical Society, 60.

[38] Christians, J.A., Fung, R.C.M. and Kamat, P.V. (2014) An Inorganic Hole Conductor for Organo-Lead Halide Perovskite Solar Cells. Improved Hole Conductivity with Copper Iodide. Journal of the American Chemical Society, 136, 758-764. http://dx.doi.org/10.1021/ja411014k

[39] Kossoy, A., Merk, V., Simakov, D., Leoson, K., Kena-Cohen, S. and Maier, S.A. (2015) Optical and Structural Properties of Ultra-Thin Gold Films. Advanced Optical Materials, 3, 71-77. http://dx.doi.org/10.1002/adom.201400345

[40] Zainun, A.R., Noor, U.M. and Rusa, M. (2011) Electric and Optical Properties of Nanostructured Copper(I) Iodine (CuI) Incorporated with Ligand Agent for Dye Sensitized Solar Cell Application (DSSC). International Journal of the Physical Sciences, 6, 3993-3998.

[41] Bailie, C.D., Christoforo, M.G., Mailoa, J.P., Bowring, A.R., Unger, E.L., Nguyen, W.H., Burschka, J., Pellet, N., Lee, J.Z., Grätzel, M., Noufi, R., Buonassisi, T., Salleo, A. and McGehee, M.D. (2015) Semi-Transparent Perovskite Solar Cells for Tandems with Silicon and CIGS. Energy \& Environmental Sciences, 8, 956-963. http://dx.doi.org/10.1039/C4EE03322A 